\title{
Király Pál and the Hungarian Submachine Guns
}

\author{
SOÓS Péter ${ }^{1}$
}

\begin{abstract}
Király Pál was one of the best-known Hungarian weapon designers, whose name has become a synonym for the submachine guns he constructed. His confusing per- sonality and puzzling career well reflect an eventful and chaotic period of $20^{\text {th }}$ cen- tury Hungarian history. When his most successful creations, the Király submachine guns, were being developed, no experience regarding the military usage of such weapons was available at all. Consequently, when designing and manufacturing the weapons, the closely cooperating military supreme command and ammunitions in-dustry faced several initial problems. Although the continuing development proved successful, production capacity fell behind the growing needs of the military for au-tomatic handguns. The present work aims at introducing the famous engineer's life and activity, as well as the phases of weapon development and production history. Keywords: weapon designer, WW I, submachine gun, armaments factory, weap- on development, breech mechanism, high performance cartridges, WW II, feeding problems, redesigning, subtypes
\end{abstract}

\section{Introduction}

As in the case of other new types of arms, submachine guns were brought into being by the new combat conditions of WW I. Besides their small size and high rate of fire, the submachine guns were easier to handle in the trenches, mountains and in close combat conflict and facing technical obstacles. In the last years of the war attempts were made to transform self-loading, pistol cartridge firing handguns into automatic firearms, and special constructions made their appearance on the battle fields. The first gun of this type was the $9 \mathrm{~mm}$ Italian Villar-Perosa submachine gun, which was rather a sort of light machine gun. [1: 230-241] Several dif- ferent kinds of submachine gun, named "assault pistol" were used in the Austro-Hungarian army, and several factories and arms designers were involved in the construction of such arms, namely the director of the Arms and Machine Factory Plc., (Fegyver- és Gépgyár Rt., Budapest) Frommer Rudolf. ${ }^{2}$ After the end of WW I, in compliance with the peace treaties, the Hungarian army was downsized and the capacity of military industry was considerably reduced. In order to circumvent the restrictions, many of the companies, in cooperation with the Ministry of Defence, carried out the new arms developments in secret, thus avoiding de- tection by international observers. One of the factories involved in secret arms developments was the Budapest based Danuvia Arms and Ammunition Factory Plc. (Danuvia Fegyver és Lőszergyár Rt.) carrying out arms development and manufacturing from the mid 1920s. The small but modern factory was specialized in manufacturing and developing automatic infan- try and board-arms. [2: 19-34]

1 Institute and Museum of Military History, Hungary, Budapest, e-mail: soos.peter@mail.militaria.hu

2 Hungarian weapon designer, 1868-1936. 


\section{The Life of Király Pál}

Király Pál was born in 1880, in Budapest, and was one of the arms designers working to revive the Hungarian arms industry. Király, who was of noble birth, after taking a degree in mechanical engineering in 1902, attended a one-year training course for reserve officers in the Austro-Hungarian Army, and on the basis of his qualification joined the artillery. His took out his first patent for a semi-automatic pistol with simple blowback mechanism in 1910. In 1914, he was called up for military service in his regiment. In 1918, at the end of WW I, having earned an Artillery Captain rank, he became a reservist officer. From that time on, he dedicated himself entirely to arms design. Commissioned by the Ministry of Defence, be- tween 1921 and 1924, he designed a self-loading rifle and a light machine gun, after that he was hired by Swiss Industrial Company (SIG), located in Neuhausen, Switzerland. Although the exact title which Király had at the company is not known, he undoubtedly worked at the department developing automatic guns, headed by Gotthard End, director. Their most suc- cessful joint design project was the

Király-End (KE)-7 light machine gun, of which a few thousand pieces were exported mainly to the Far-East. Király was in charge of the design of the breech and feed mechanisms of the guns, which represent the core component of automatic guns. Apart from the light machine gun, Király's name is also associated with several self-loading rifles, of which only a limited number were manufactured. [3] In 1928, his relationship with the company man- agement must have deteriorated, therefore, he decided to pursue his activity in Hungary, at Danuvia Plc. In the 1930s he designed pistols, self-loading rifles and light machine guns, but none of them were put into series manufacturing. His most outstanding design achievements are the submachine guns bearing his name, which he designed from 1939, along with a large number of experimental arms. During the years of WW II Király continuously strived to improve his guns, in close cooperation with the Institute of Military Technology, an establish- ment of the Ministry of Defence in charge of military development. Following WW II Király was employed by the Ministry of Industry, but it seems his financial situation deteriorated considerably. He tried to draw the attention of the new Hungarian military elite to his inven- tions, but in vain. In order to resolve his difficulties, he attempted to sell his patents abroad, but this move did not pass unnoticed by the authorities. In 1947, he travelled to Switzerland again hoping to straighten out his finances with the help of his past connections. That was when he met his fellow citizen, Kovács Alexander, who had been given a free hand and five million dollars by the dictator of the Dominican Republic, Rafael Trujillo, to establish an arms factory. After negotiations lasting several months, Király finally accepted Kovács's offer and travelled to the Caribbean country. In the factory set up in San Cristobal Király Pál pursued his designer activity based on his experiences gained in Switzerland and Hungary, and managed to develop, together with his colleagues, a successful submachine gun range, named Cristobal. Trujillo was assassinated in 1961, which meant Király lost the ground from under his feet once again. To secure a living, he most probably tried to sell his patents and designs, of which the Dominican secret services must have disapproved, and presumably murdered the Hungarian arms designer, who was then aged over 80. [4] 


\section{The M 1939 Submachine Guns and Its Subtypes}

After WW I no submachine guns were adopted in the reorganised Hungarian army until the mid 1930's, the rifles being considered were suitable solely for law enforcement purposes. The situation changed around 1938 when, using the experiences of ongoing armed conflicts, comparative trial shootings of the European top level submachine guns were conducted by the Institute of Military Technology.

The breakthrough technology was the patent for a gun jointly designed by Király Pál and Kucher József, leading engineers of Danuvia Plc., commissioned by the Hungarian Gendar- merie and the Police. The technical solutions which Király got to know during the years spent in Switzerland, especially the SIG MKMS submachine gun, represented the basis of the new Hungarian submachine gun. Both submachine guns, characterised by a full length fore-end, similar in shape and size, could be mounted with bayonet and folding magazine. Never- theless, the essential difference between the two guns was the unique breech mechanism featured by the Hungarian rifle. The complex, thoroughly machined breech mechanism was needed because of the high performance cartridges used by the Hungarian submachine gun. The Király submachine guns in fact did not fire the standard $9 \times 19 \mathrm{~mm}$ Parabellum cartridge, commonly used by the European armies, but the $9 \times 25 \mathrm{~mm}$ Mauser Export cartridges. The designers increased the energy absorbing capacity of the breech mechanism so as to design a relatively light gun capable of firing high performance cartridges. The breech mechanism was divided into two parts gliding on each other, with a separate and delayed blowback. The real innovation of the chief engineers of Danuvia Plc. was that, as opposed to the Swiss made submachine guns, the two breech-blocks were connected with a so called push-back lever, the positive push and friction were meant to absorb partially the blowback. The technical solution proved to be efficient, but the relatively complicated structure made production labour intensive and costly.

The new submachine gun having successfully passed the test in the presence of the repre- sentatives of the Hungarian police and Institute of Military Technology, Danuvia Plc. offered the model also to the Royal Hungarian Army at the end of 1938. Following a few minor modifications and succesful test shootings and field evaluations, the leaders of the Army adopted the new rifle under the name "submachine gun M 1939". It is mentioned in tech- nical reports on several occasions that the Király submachine gun is of an excellent design, surpassing submachine guns of similar use in many respects. Higher initial cartridge speed, lower weight, high capacity magazine and parts not requiring greasing were the features highlighted in the reports. Meanwhile, military experts differed about the possible uses of the submachine guns in the battle fields. They expected the Király submachine guns, because of their higher penetration ability and longer effective range, to replace the self-loading pistols and become a basic gun of the Hungarian Army. By adopting the Király submachine gun, the Institute of Military Technology made an important step towards a yet nonexistent category of rifles, the assault rifle with intermediate cartridge.

The adoption of the submachine gun M 1939 was not immediately followed by a larger order. Out of the first lot of 1566 submachine guns only 276 were manufactured for the Hungarian Army, namely, for its elite parachute battalion. However, parachuters complained about the length of the submachine guns, representing an obstacle during test jumps with 
arms, and requested a folding stock version from the authorities. Thank to the joint efforts of the Institute of Military Technology and Danuvia Plc., the first subtype of the submachine gun, named M 1939/A, was designed with a hinge allowing the folding of the stock to the side, thus reducing the length of the rifle by one third. No original example was preserved of the submachine gun 1939/A. ${ }^{3}$

The process of adopting the accessories of the Király submachine gun took place in 1941-1942. The magazine case holding altogether six magazines, each containing 40 car- tridges was made of linen, allowing the fixing of a magazine loading machine, too. The magazine loading machine could load 10 cartridges simultaneously, the cartridges being kept together with a loading clip. The submachine gun could be carried with the help of the gun slings generally used in the army. The bayonet used for the M 1935 rifle could be attached to the submachine guns. [5: 70-74]

The military events of $1941 / 42$ proved that not only the arsenal of elite troops was lacking automatic handguns. Therefore, the General Staff expected to use a significant number of submachine guns in the battle order "Huba" III. Upon the mobilisation of the Hungarian $2^{\text {nd }}$ Army in spring 1942, the available number of Király submachine guns was not sufficient, therefore, the troops had to be armed with 5000 pieces of $9 \mathrm{~mm}$ MP40 submachine guns provided by the German Army. [6: 32]

Although the latter proved to be effective, the experts at the Ministry of Defence contin- ued to believe the future lied in the Hungarian submachine gun. Their objective was to put into service a gun which was smaller than a selfloading rifle but more powerful than the submachine guns. This plan did not fulfil the expectations for several reasons, one of which was that even a high performance pistol cartridge could not be efficient in a combat situation where a gun using a rifle cartridge was efficient. The other huge problem was the rifle shape itself. In spite of better shooting accuracy, better aiming accuracy and the possibility to attach a bayonet, the M 1939 Király submachine gun lacked precisely what characterised the sub- machine guns: easy handling and portability.

Nevertheless, the real problem regarding the Király submachine guns was of a different kind: the imperfect structure and the recurrent operational obstacles arising due to the lack of ammunition supply and low material quality represented the major shortcoming. In order to remedy the shortcomings, the charge of the cartridges was modified and reduced, the problematic parts were redesigned. As most of the feeding problems originated in connec- tion with the magazines, the $90^{\circ}$ inclination angle of the magazines was changed during the experiments, and the movable ejector built in the breech mechanism was replaced by a fixed ejector installed in the receiver. Although the M $1939 / 42$ submachine guns remained in the test phase, they created the basis for further developments. As it was essential that the stocks, which had been manufactured, went into service, the user manual of the submachine gun had to be completed with a few rules necessary for safe operation.

\section{The M 1943 Submachine Guns and Its Variants}

The idea of redesigning the gun created a new possibility for the decision makers as far as submachine gun standards were concerned. On the basis of military experiences it became

3 The computerised 3D reconstruction of the model was made by the employees of the Hungarian Museum of Military History in 2012. 
clear that troops needed a lighter) weapon apt for close combat, allowing the quick change of the target rather than a low performance self-loading rifle. Consequently, requirements regarding dispersion pattern and energy of impact were mitigated, and Danuvia Plc. was com- missioned to design the lightened and shortened version of the Király submachine guns. Fol- lowing a number of trial shootings in which various test guns were used, the jury selected and serviced the best model, which became later known as the M 1943 Király submachine gun.

The design of this submachine gun fulfilled the needs of the army with its shorter barrel and shoulder-piece which could be folded under the fore-end. Based on the solutions of the submachine gun M 1939/42, the position of the breech and the magazine housing were mod- ified, which also implied the modification of the outer design of the latter. The possibility to fit the submachine gun with a bayonet was kept, and the sight and the firing-selector and safety lever remained unchanged. The M 1943 submachine gun fired the same 1939 M 9 mm Mauser cartridge. Although in 1942 attempts were made to redesign the Király submachine guns for Parabellum cartridges in view of an easier ammunition supply, the possibility was later abandoned.

In 1942, the Ministry of Defence made a large order of M 1939 submachine guns to Danuvia Plc., representing 45 000 pieces, the accessories and spare parts included. The adop- tion of the new model did not mean the cancellation of the order, and the factory was instruct- ed to start manufacturing the M 1943 submachine guns without delay. The manufacturing of the M 1939 submachine gun finished in spring 1944, and the total number of guns taken over reached 13322 pieces. Having changed over to the manufacturing of M 1943 type, Danuvia Plc. planned to purchase new equipment and built a new factory hall. Even by working at an increased capacity, the factory could have kept the delivery deadline if continuous raw mate- rial supply was assured by the Ministry of Defence. The manufacturing of submachine guns became a priority for the military direction, which intended to involve the Metalware, Arms and Machine Factory Plc. (Fémárú- Fegyver és Gépgyár Rt.) in the production. The technical description and the drawings were handed over as early as in 1943, but due to machinery and raw material shortage, the bombings and the subsequent evacuation of the factory, mass production was never launched in the plant. [7: 306-311]

Unlike in the case of its predecessor, no detailed description nor reports were preserved regarding the usability and the characteristics of the M 1943, although it is most likely those feeding problems were still not resolved. In order to overcome operational difficulties and facilitate manufacturing, a simplified version of the gun with a one-piece simple blowback mechanism was designed. By changing the breech, the recoil spring and the receiver's end- cap, the M 1943 submachine guns could be transformed into a blowback version within field conditions.

Submachine gun manufacturing became an urgent issue in the worsening war situation, and the adequate solution seemed to be the further simplification of the gun. The last war- time version of the Király submachine guns, designated incorrectly as M 1944 Danuvia Plc. version, was designed in this spirit. In the design of the new version Király Pál was assisted by technical supervisor Győrik József. Their joint invention, the "blowback mechanism with loosely locked divided breech" returned again to the idea of two-piece breech mechanisms, in which instead of a lever a simple spring was mounted in the breech mechanism for recoil absorption. Cushioning the blowback impact was of major importance in the case of a so- called "compact" submachine gun. The shoulder-piece was completely removed, and the 
fore-end was reduced to a barrel jacket around the shortened barrel. The receiver and the trigger mechanism were simplified, the magazine housing became fixed. It is not known how many of these submachine guns were manufactured, probably not more than a few pieces.

The manufacturing of M 1943 submachine guns was delayed several months due to the raw material shortage, which became alarming when the bombings started by the Allies in April 1944. First, the submachine manufacturing lines were moved into various cellars in Budapest, and later into different location in Western Hungary as the Soviet Army was ap- proaching the capital. Nevertheless, it was no longer possible to re-launch manufacturing. Presumably, 15000 to 20000 pieces were manufactured of the M 1943 model.

The partial dismantling and subsequent transporting or destroying of the manufacturing lines did not mean the end of the story of the Hungarian submachine guns in WW II. After the front passed, the workers of Danuvia Plc. returned to the Budapest factory, damages were assessed, a part of the machinery was made operational again, and the remaining raw materials were put on the inventory. As soon as the fights ended in the Transdanubian region a larger order of $\mathrm{M}$ 1943 submachine guns was placed by the direction of the new Ministry of Defence.

The Hungarian Army of the period between 1945 and 1948 kept the Király submachine guns in service, most likely until the existing stocks expired. The Soviet rearming after the communist overturn sealed the fate of the Hungarian handguns manufactured before and during WW II. In 1950, a part of the remaining Király submachine guns were transformed in Danuvia Plc. so they could fire the soviet M $19337.62 \times 25 \mathrm{~mm}$ Tokarev pistol cartridge. The M 1950 version submachine gun actually used the M1943 spare part base, the only import- ant difference between the two versions being the barrel and the barrel jacket. It would be difficult to estimate the number of these guns as no documents were found in which they are mentioned. Based on the testimony of contemporary photos, the M 1950 submachine guns serviced second line armed corps, such as bridge, factory and railway guard brigades.

\section{Summary and Conclusions}

Even today the Király submachine guns are among the most widespread Hungarian WW II guns, they are the most prized treasures of public and private collections. Although they do not necessarily deserve to be referred to as "the best submachine gun of WW II", as it can be often read on the Internet, it would be a mistake to underestimate their significance. The Király submachine guns recall a period when independent Hungarian arms design and man- ufacturing still existed, the military leadership displayed interest in innovative solutions, and tried to pave the way for new Hungarian technical development and products.

The Király submachine guns resemble other Hungarian armament products of the Second World War of which too few were manufactured and too late. Although these guns were not perfect technically, their unique and smart technological solutions classify them as outstand- ing products in Hungarian and international weapons history. Experts and laymen dealing with armaments worldwide consider them distinguished symbols of Hungarian weapon pro- duction during World War II. 


\section{References}

[1] ORTNER, M. C.: Sturmtruppen, Österreichisch-ungarische Sturmformationen und Jagdkommandos im Ersten Weltkrieg. Wien: Verlag Militaria, 2005.

[2] GÁSPÁR F., MANN M.: Danuvia Központi Szerszám- és Készülékgyár története. Budapest: Magyar Történelmi Társulat Üzemtörténeti Szakosztálya, 1971.

[3] SOÓS P.: Egy magyar fegyvertervező Svájcban - Király Pál tevékenysége az SIG-ben. In. ZÁVODI Sz. (Ed.): Hadtörténeti Múzeum értesitőjje, 13 (2013), 153-168.

[4] DOMINGO, L.: A magyar bevándorlók szerepe a Dominikai Köztársaság iparosításában. In. KOVÁCS N. (Ed.): Tanulmányok a diaszpóráról. Budapest: Gondolat, MTA Kisebbségkutató Intézet, 2005, 139-149.

[5] Anyagismeret. 39 M. (39/A M.) géppisztoly. F 11/d. (Tervezet), Budapest: M. kir. honv. Haditechnikai Intézet, 1942.

[6] SZABÓ P.: Don-kanyar, a magyar királyi 2. honvéd hadsereg története 1942-1943. Budapest: Corvina Kiadó, 2001.

[7] DOMBRÁDY L.: A magyar hadigazdaság a második világháború idején. Budapest: Petit Real Könyvkiadó, 2003.

\section{Related sources}

EÖTVÖS P., HATALA A., SOÓS P.: A Király géppisztoly. Budapest: Zrínyi Kiadó, 2014. 